\title{
Assessment of Loan Repayment Performance of Smallholder Farmers: The Case of Gubalafto District, North Wollo Zone, Amhara National Regional State, Ethiopia
}

\author{
Bogale Belay \\ Wollo University, Agriculture, Agricultural Economics: P.O Box. 1145, Dessie: 0930979727
}

\begin{abstract}
The main objective of this study was to assess loan repayment performance of smallholder farmers in Gubalafto district of North Wollo Zone. A two-stage sampling technique was employed to select a total of 140 sample borrowers. The two-limit Tobit model and descriptive statistics were used to analyze the data collected from the sample respondents. The descriptive statistics result indicates that about 27 percent of the sampled households are low performer and the remaining 73 percent were high performers of loan. In addition, the descriptive statistics results revealed that there were significant mean differences between the low and high repayment performance group in the study district with respect to age of the borrowers, sex, distance from credit source, education level, total land size, Loan amount received, livestock holding and purpose of borrowing. The maximum likelihood estimate of the two Limit Tobit model results indicate that 13 variables were considered in the econometric model out of which, 7 variables were found to significantly influence loan repayment rate among the farm households at less than 5 percent level of significance. Age of borrowers, Educational level of borrowers, land size, total livestock holding and Off-farm income positively and significantly influenced the intensity of loan repayment while, Distance to credit source and Loan amount received negatively influenced the loan repayment rate of small holder farmers in the study area.
\end{abstract}

Keywords: Loan repayment performance, Tobit model, Gubalafto District

DOI: $10.7176 / \mathrm{JBAH} / 10-7-03$

Publication date: April $30^{\text {th }} 2020$

\section{INTRODUCTION}

Agriculture is the main stay of Ethiopian economy where it holds the key of rapid economic development because of its size, potentiality for growth and capacity to transform the entire outlook of economy. The contribution of agriculture in GDP is about $41 \%$, providing employment to almost $85 \%$ of the population and $86 \%$ of the country's export earnings (Matthew, 2011). According to IMF, Ethiopia's GDP growth was $8.2 \%$ in2013/14 and 8.5 in 2014/15

Basically, rapid growth of agricultural productivity is improved through the expansion and implementation of new agricultural technologies and the use of credit facilities. However, with the introduction of new production technologies, the financial needs of farmers increase. Steady agricultural development depends up on the continuous increase in farm investment which requires increasing use of modern agricultural inputs such as fertilizers, tractors and improved seeds. This implies that local farmers with small scale operation, low productivity, low income and inability to purchase these modern requisites needed to be supplied with credit facilities to generate increased productivity (Ololade and Olagunju, 2013).

Most financial institutions in developing countries provide collateral free small loans to low income productive poor farmers and services like saving and credit to aid several smallholder farmers. This is an effort in line with the "Millennium development goals" in order to relieve financial constraints and reduce poverty by $50 \%$ by the year 2015 (Solomon, 2013). However, the sustainability and continuity of the financial institutions to increase the volume of credit to stimulate the poverty reduction goal depends on the repayment rates. High repayment rates are associated with benefits of both MFIs and the borrowers. High repayment rate helps to obtain higher amount of next loan (Fikirte, 2011) and also enables MFIs to lower the interest rates and processing costs and consequently reduce the dependence of the credit institutions on subsidy and enables them to reach a better sustainability level. Better repayment performance thus serves as a positive signal for increasing the volume of credit availability to various sectors of the economy. However, the financial institutions continue to decline credit to the agricultural sector due to poor loan repayment performance from these sectors.

The provision of loan has increasingly been regarded as an important tool for raising the incomes of urban as well as the rural populations, mainly by mobilizing resources to more productive uses (Kibrom, 2010). However, smallholder farmers face severe shortage of financial resources to purchase productive agricultural inputs due to continuous increase in prices of inputs and the relatively low level of farm income. Consequently, the hope of the subsistence farmer on financial institutions for credit has become substantially higher in the recent times and failure by farmers to repay their loans on time or to repay them at all has been a serious problem faced by both agricultural credit institutions and smallholder farmers (Million et al., 2012). Credit and saving services have a great potential 
to increase the risk bearing capacity of borrowers and microfinance may help them cope up with disaster and in more limited manner reduce direct risk exposure through income if the borrowed fund is invested in productive activities that can generate additional income to repay loans to the lending institutions and have sustainable and viable production processes.

In countries like Ethiopia where subsistence agriculture prevails and small-holder farming dominates the overall national economy, farmers often face a scarcity of capital (saving) to adopt new agricultural technologies and to purchase productive agricultural inputs. Credit provision (fertilizer, improved seeds, pesticide and herbicides) is one of the principal components of rural development which helps to attain rapid and sustainable growth of agriculture. Rural credit is a temporary substitute for personal savings, which catalyzes the process of agricultural production and productivity. To boost agricultural production and productivity farmers have to use improved agricultural technologies. However, the adoption of modern technologies is relatively expensive and smallholder farmers cannot afford to self-finance (million, 2012). Therefore, the provision of sustainable credit for agricultural inputs is one of the most effective strategies for improving productivity among the resource poor farmers.

Financing of agricultural inputs and labor wages requires liquid cash that often is not readily available with the smallholder farmers. Therefore, it is essential to expand the status of rural credit at large to improve agricultural productivity. But increasing default rate is one of the main problems of poor performance of the lending institutions (Mokhtar etal, 2012, Osman etal, 2017).

The process of issuing loans by the financial institutions goes hand in hand with risks such as loan repayment risks, liquidity risks. In order for the financial institutions to reduce risks, they should establish appropriate and effective loan repayment environments. This could include operating under sound loan provision processes, maintaining an appropriate loan repayment administration, having clear procedures and criteria for evaluating a loan application, organized documentations and release of credits, efficient internal control systems and demanding adequate and easily attainable collaterals (Million et al., 2012).

Despite the efforts made to collect loans, available data indicates that many financial institutions still face poor loan repayment performance due to the fact that not all loans disbursed are repaid on the due date (Robert, 2014). With this borrowers' failure to repay the loans, the financial institutions are unable to provide loans to new loan applicants (Fikirte, 2011). It is also fundamentally known that poor loan repayment behavior by the borrowers negatively affects the financial institutions' operations in a number of ways. These include the inability of the financial institutions to fully disburse the loans at the expected maximum levels.

It is obvious that many rural credit schemes have sustained heavy losses because of poor loan collection. And yet a lot more has been dependent on government subsidy to financially cover the losses they faced through loan default (Firafis, 2014). Since there is low repayment performance in rural borrower, it discourages the lender to promote and extend credit to large and fragmented farm households and hinder the realization of sustainability of MFIs (pasha and Tolosa, 2014). It is therefore, important for the financial institutions to devise means to reduce the levels of loan default within economic sectors.

According to GubaLafto Woreda agriculture and rural development office, loans that have been disbursed by different institutions in the past few years have not fully been repaid. The Regional Government and Amhara credit and saving institution provides small scale and agricultural loan for economically productive poor farmers through the group lending approach using peer pressure as a substitute for collateral.

This micro-finance institution provides credit facilities to farm households in the study area in order to narrow the gap between the capital required and the capital that farmers possess, for the improvement of agricultural technologies that would increase production and productivity (Million, 2013). However, there is a serious loan repayment problem in the study area. Many studies which are conducted on microfinance institution largely focus on analyzing the probability that the borrower is being defaulter not the actual loan repayment performance of borrowers and so far no scientific studies has been conducted regarding to loan repayment performance of smallholder farmers in the study area. In addition, the study district is known for its use of high amount of inputs and high labor use during peak periods of harvesting and weeding (celebrate more social festivals) which requires capital. In line with these problems this study will provide insight into this less studied dimension by assessing the loan repayment performances of smallholder farmers in the study area. Therefore, this study was conducted with the following objectives.

1. To compare high loan performer and low loan performers in terms of different explanatory variables.

2. To analyze the factors that are likely to affect the loan repayment performance and the loan repayment rate among smallholder farmers in the study area.

3. To identify the major problems and challenges faced by the borrowers and lenders in the repayment process. 


\section{RESEARCH METHODOLOGY}

\subsection{Description of the Study Area}

The Federal Democratic Republic of Ethiopia (FDRE) is administratively divided into nine national regional states and two administrative councils. The Amhara National Regional State (ANRS) is one of the nine National Regional States. The ANRS is again divided into eleven administrative zones, one of which is North Wollo (CSA, 2005). Guba Lafto is one of the 105 districts in the Amhara National Regional State and one of the 33 districts of North Wollo administrative zone. Guba Lafto is bordered on the south by Debub Wollo zone, on the west by Delanta and Wadla, on the north by Gidan, and on the north east by the Logiya River which separate it kobo, and on the southeast by Habru. Towns in this woreda include Hara.

Based on the 2007 national census conducted by the Central Statistical Agency of Ethiopia (CSA), this woreda has a total population of 139,825 , an increase of $0.48 \%$ over the 1994 census, of whom 70,750 are men and 69,075 women; 4,886 or $3.49 \%$ are urban inhabitants. With an area of 900.49 square kilometers, Guba Lafto has a population density of 155.28 , which is greater than the Zone average of 123.25 persons per square kilometer. A total of 33,676 households were counted in this woreda, resulting in an average of 4.15 persons to a household, and 32,824 housing units. The majority of the inhabitants practiced Ethiopian Orthodox Christianity, with 86.58\% reporting that as their religion, while $13.32 \%$ of the population said they were Muslim.

The Woreda has a mountainous landscape ranging from 1300 to 3900 meters above sea level (Svein Ege, 2002). The topography of the area is characterized by $20 \%$ flat, $30 \%$ undulating, $35 \%$ mountainous and $15 \%$ gorges or valleys. GubaLafto Woreda has four agro-ecological zones, namely, lowland (Kolla) which ranges from 1300-1500 masl, mid-altitude (Weinadega) ranges from 1500-2300 masl, Highland (Dega) ranges from 2300-3200 masl and Wurch > 3200 masl. According to the data collected by Sirinka Agriculture Research Center (located about $10 \mathrm{~km}$ south of Woldiya), the mean monthly temperature ranges between $21^{\circ} \mathrm{c}$ to $25^{\circ} \mathrm{c}$. A bi-modal nature of rainfall characterizes most parts of GubaLafto woreda. The short rainy season (Belg), occurs between February and April while the long rainy season (Meher), occurs between June and September. In most cases, the highland areas (Dega) are mainly dependent on Belg rain whereas, the Weinadega and Kolla areas are dependent more on Meher rain for their crop production. The main crops grown in the study area are cereals (maize, sorghum, teff and wheat), pulses (peas and bean), fruits (banana, papaya, orange and mango) and rice is new technology introduced in the area. The main livestock species reared in the zone are cattle, sheep, goats and poultry (GubaLafto Woreda Administration, 2013).

\subsection{Data Sources and collection methods}

The study has employed both primary and secondary data. Primary data was collected from sample households through a well- prepared and pre-tested interview schedules that were administered to the respondents by the trained enumerators. Training was given to the enumerators to develop their understanding regarding the objectives of the study, the content of the questionnaire, how to approach the respondents and conduct the interview. Secondary data related with loan repayment performance of smallholder farmers has been collected from appropriate published and unpublished data, Guba Lafto district Agricultural and rural development office (GDOA), Amhara credit and saving institution (ACSI).

\subsection{Sampling technique and sample size}

A two-stage sampling method was employed to obtain the necessary information from farmers' taking loans. At the first stage, four kebeles of GubaLafto district were selected purposively because they are the leading user of credit with long years of experience and adequate information for the research at hand. In the second stage, using a probability proportional to size sampling technique 140 sample borrowers were selected randomly using Cochran's (1963:75) method. This study used a 95 percent confidence interval $(Z=1.96)$ for a two tail test, and assuming that $\mathrm{P}=0.1$ with an allowable error of 5 percent.

\subsection{Method of Data Analysis \\ 2.4.1 Descriptive statistics}

Descriptive statistics analysis was used to summarize the data collected from sample respondents to associate demographic and socioeconomic characteristics of respondents with repayment performance. These mean, percentage, standard deviation, frequency distribution, t-test and Chi-square test statistics were employed to compare the low and high performer group in terms of each explanatory variable.

\subsubsection{Econometric model}

In this study the value of the dependent variable is repayment ratio which is computed as the ratio of amount of loan repaid to the total amount borrowed. Thus, the value of the dependent variable ranges between 0 and 1 and a two-limit Tobit model which is based on maximum likelihood technique was used as a more appropriate econometric model based on Maddala, (1983) and Gujarati (2004). The structural equation of the Tobit model is given as: 
$Y^{*}=\beta X i+\varepsilon i, \varepsilon \sim N\left(0, \delta^{2}\right)$

Denoting Yi as the observed dependent (censored) variable

$Y i=\left\{\begin{array}{c}L \text { if } Y^{*} \leq L \\ Y^{*}=\beta X i+\text { ei if } L<Y^{*}<U \\ U \text { if } Y^{*} \geq U\end{array}\right\}$

Where

$\mathrm{Y}_{\mathrm{i}}=$ the observed dependent variable, in our case repayment ratio

$\mathrm{Yi}^{*}=$ the latent variable (unobserved for values smaller than 0 and greater than 1 )

$\mathrm{X}_{\mathrm{i}}=$ is a vector of independent variables that influence repayment rate

$\beta_{i}=$ vector of unknown parameters associated with the independent variables to be estimated

$\varepsilon \mathrm{i}=$ Residuals that are normally distributed with mean zero and a constant variance

$\mathrm{i}=1,2 \ldots \mathrm{n}$ ( $\mathrm{n}$ is the number of observations).

$\mathrm{L}=$ lower limit, $\mathrm{U}=$ upper limit

\subsection{Definition of variables and working hypothesis}

\subsubsection{Dependent variable}

The dependent variable is the loan repayment rate which is computed as the ratio of amount of loan repaid to the total amount borrowed. Its value ranges between 0 and 1 inclusive.

\subsubsection{Explanatory variables of the study}

The main explanatory variables of this study are: Age of the borrower, Sex of respondent, Family size, Education level, Land size, Number of livestock owned, Off-farm income, Celebration of social ceremonies, Experience in formal credit use, Distance from credit source, Amount of loan, Purpose of borrowing and Shock.

\section{RESULTS AND DICUSSION}

\subsection{Descriptive Results}

3.1.1 Demographic and socio-economic characteristics

Loan repayment performance: An outcome variable which is computed based on loan repayment rate in order to classify borrowers into two categories. Those households whose repayment rate greater or equal to $0.5(\mathrm{LRR}>=0.50)$ were assigned as high performers of loan while below $0.5(\mathrm{LRR}<0.50)$ were assigned as low performers (Chukwudi, 2013). The cut-off point is determined as the midpoint of the repayment rate to maintain misclassification.

Table 1: Descriptive statistics of continuous variable by the repayment performance

\begin{tabular}{|l|l|l|l|l|l|l|l|l|}
\hline $\begin{array}{l}\text { Repayment } \\
\text { performance }\end{array}$ & AGE & DCRS & FAMS & LANDSZ & LOANREC & TLU & OFFINC \\
\hline Low & Mean & 39.74 & 12.66 & 4.16 & 0.64 & 16105.26 & 3.14 & 5673.68 \\
\hline & SD & 0.71 & 3.32 & 1.39 & 0.26 & 5441.53 & 1.33 & 4741.97 \\
\hline & Minimum & 23 & 5.00 & 1.00 & 0.25 & 6000 & 0.00 & 0.00 \\
\hline & Maximum & 67 & 18 & 7.00 & 1.25 & 28000 & 5.98 & 24000 \\
\hline High & Mean & 46.14 & 8.38 & 4.97 & 1.20 & 14185.29 & 5.14 & 6874.51 \\
\hline & SD & 11.52 & 3.30 & 1.58 & 0.34 & 6052.99 & 2.28 & 3939.18 \\
\hline & Minimum & 24 & 3.00 & 1.00 & 0.50 & 3000 & 1.26 & 0.00 \\
\hline & Maximum & 69 & 19 & 9 & 1.75 & 40000 & 9.28 & 15800 \\
\hline Total & Mean & 44.4 & 9.54 & 4.75 & 1.05 & 14706.43 & 4.60 & 6548.57 \\
\hline & SD & 11.62 & 3.81 & 1.56 & 0.41 & 5936.20 & 2.25 & 4189.01 \\
\hline & Minimum & 23 & 3 & 1 & .25 & 3000 & 0 & 0 \\
\hline & Maximum & 69 & 19 & 9 & 1.75 & 40000 & 9.28 & 24000 \\
\hline & t-value & $-2.9 * * *$ & $6.8 * * *$ & $-2.79 * * *$ & $-9.09 * * *$ & $1.7 *$ & $-5.1 * * *$ & -1.5153 \\
\hline
\end{tabular}

Note $* * *$ and $*$ refers level significance at $1 \%$ and $10 \%$ respectively,

Source: Own survey 2018

Age: The average age of the whole sampled household heads was 44.40 years with the minimum and maximum ages of 23 and 69 years, respectively. The average age of households having low repayment performance was 39.74 years while that of the high performer was 46.14 years with mean difference significant at $1 \%$. This indicate households with high repayment performance are aged than the low performer, which helped them to accumulate better wealth and able to repay their debt in time than youngsters (Table 3).

Distance to credit source (in $\mathbf{k m}$ ): The average distance traveled by the respondents to the credit source was about 9.54 kilometers. On average, smallholder farmers having high repayment performance traveled about 8.38 kilometers while farmers with low repayment performance traveled 12.66 kilometers to reach the institution with statistically significant mean difference in distances traveled by the two groups at $1 \%$ (Table 3 ). Possible 
justification for this result is that farmers near the lending institutions have advantageous on getting new information daily, save farm resources (time, labor) which otherwise would have been spent to access different financial products and services.

Family size: The average family size of the sample households was 4.75 with maximum and minimum family size of 9.00 and 1.00 respectively. The mean family size of respondents having low and high repayment performance was 4.16 and 4.97 respectively with significant mean difference between the two groups at $1 \%$ significance level (Table 3).

Land size: The average size of total cultivated land was nearly 1.05 hectare with minimum and maximum of 0.25 and 1.75 ha, respectively (Table 3 ). As witnessed by the survey results, the mean land size of household having low and high repayment performance was found to be 0.64 and 1.20 hectares, respectively. The mean comparison of the two groups in terms of mean cultivated land size revealed significant difference between the two groups at $1 \%$ significance level. This implies that high performers have large farm size as compared to low performers, and that enable to produce more farm output which helped them repaid their loan, being other factors ceteris paribus. A farmer with more hectares of land is better off in loan repayment performance.

Amount loan received: The sample households on average borrowed Birr 14706.43. The descriptive result also revealed that Birr 16105.26 and 14185.29 was borrowed by farmers having low and high repayment performance with significant mean difference among the two groups at $10 \%$ significance level.

Livestock holding: The survey result demonstrated that sample households in the study area on average owned 4.60 TLU, with a minimum of 0.00 and a maximum of 9.28 TLU. Low and high performer households have mean TLU of 3.14 and 5.14 respectively with statistically significant mean differences in livestock holding between the two groups at $1 \%$ level of significance (Table 3). This implies that livestock is an important asset for farmers not only to perform farm activities such as draught power, to generate income, to secure food and to cover different social, economic and legal expense, but also contribute to secure cash to pay debts.

Off-farm income: The income generated from off-farm activity ranges from no income to a maximum of Birr 24,000.00. The mean annual off-farm income of sample households was found to be Birr 6548.57. On average, high performers earned 6874.51 Birr/year from non-farm activities while the low performers earned 5673.68 Birr/year with insignificant mean difference in annual off-farm income between the two groups (Table 3 ).

Table 2: Descriptive statistics of discrete variables by repayment performance

\begin{tabular}{|c|c|c|c|c|c|c|c|c|}
\hline \multirow[t]{4}{*}{ Variables } & & \multirow{2}{*}{\multicolumn{7}{|c|}{ Repayment performance }} \\
\hline & & & & & & & & \\
\hline & & \multicolumn{2}{|c|}{ Low } & \multicolumn{2}{|c|}{ High } & \multicolumn{2}{|c|}{ Total } & \multirow{2}{*}{$\begin{array}{l}\text { Pearson } \\
\text { chi2 }\end{array}$} \\
\hline & & No & $\%$ & No & $\%$ & No & $\%$ & \\
\hline \multirow[t]{3}{*}{ SEXBOR } & Male & 24 & 63.16 & 47 & 46.08 & 71 & 50.71 & \multirow{3}{*}{$\begin{array}{l}3.23 * * \\
(0.072)\end{array}$} \\
\hline & Female & 14 & 36.84 & 55 & 53.92 & 69 & 49.29 & \\
\hline & Total & 38 & 100 & 102 & 100 & 140 & 100 & \\
\hline \multirow[t]{3}{*}{ MSBOR } & Married & 9 & 23.68 & 35 & 34.31 & 44 & 31.43 & \multirow{3}{*}{$\begin{array}{l}1.4515 \\
(0.228)\end{array}$} \\
\hline & Unmarried & 29 & 76.32 & 67 & 65.67 & 96 & 68.57 & \\
\hline & Total & 38 & 100 & 102 & 100 & 140 & 100 & \\
\hline \multirow[t]{5}{*}{ EDUSBOR } & Illiterate & 12 & 31.5 & 16 & 15.69 & 28 & 20 & \multirow{5}{*}{$\begin{array}{l}8.45 * * \\
(0.038)\end{array}$} \\
\hline & $1-8$ complete & 14 & 36.84 & 28 & 27.45 & 42 & 30 & \\
\hline & 9-12 complete & 11 & 28.95 & 47 & 46.08 & 58 & 41.43 & \\
\hline & College $\&$ above & 1 & 2.63 & 11 & 10.78 & 12 & 8.57 & \\
\hline & Total & 38 & 100 & 102 & 100 & 140 & 100 & \\
\hline \multirow[t]{3}{*}{ CSC } & No & 9 & 23.68 & 23 & 22.55 & 32 & 22.86 & \multirow{3}{*}{$\begin{array}{l}0.0202 \\
(0.887)\end{array}$} \\
\hline & Yes & 29 & 76.32 & 79 & 77.45 & 108 & 77.14 & \\
\hline & Total & 38 & 100 & 102 & 100 & 140 & 100 & \\
\hline \multirow[t]{3}{*}{ SHOCK } & No & 13 & 34.21 & 45 & 44.12 & 58 & 41.43 & \multirow{3}{*}{$\begin{array}{l}1.1199 \\
(0.290)\end{array}$} \\
\hline & Yes & 25 & 65.79 & 57 & 55.88 & 82 & 58.57 & \\
\hline & Total & 38 & 100 & 102 & 100 & 140 & 100 & \\
\hline \multirow[t]{3}{*}{ PURBOR } & Non-Productive & 17 & 44.74 & 24 & 23.53 & 41 & 29.29 & \multirow{3}{*}{$\begin{array}{l}6.01 * * \\
(0.014)\end{array}$} \\
\hline & productive & 21 & 55.26 & 78 & 76.47 & 99 & 70.71 & \\
\hline & Total & 38 & 100 & 102 & 100 & 140 & 100 & \\
\hline
\end{tabular}

Note **refers level significance at $5 \%$

Source: Own survey 2018

Sex: The sample was composed of both male and female-headed households. Of the total sample household heads, 50.71 percent were male household heads and 49.29 percent were female household heads. About 63.16 and 36.84 percent of the low performer households were male and female-headed respectively, while 46.08 and 53.92 percent of the high performers were female and male-headed households respectively with significant mean difference between the two groups at 5\% significance level (Table 4). 
Marital status: The survey results revealed that 31.43 percent of the total respondents were married and the remaining $68.57 \%$ were unmarried. From the total low performer households 23.68 and 76.32 percent were married and unmarried respectively. In addition, 34.31 and 65.69 percent of households having high repayment performance were married and unmarried respectively. The difference between the two groups was statistically insignificant. The respondents reported that for households to participate in microfinance activities marriage is not strong criteria.

Educational Level: The descriptive results of the survey indicated that 42.86 percent of farmers in the low performance group and 57.14 percent of sample farmers in the high performance category were illiterate who were not be able to read and write a single statement. In addition, farmers with basic education 1-8, 9-12 complete and those who have college degree and above level accounts 33.33,18.97, \& 8.33 percent in the low performance group and $66.67,81.03, \& 91.67$ percent in the high performance category respectively. The Chi-square test indicated that there is systematic association between loan repayment performance and education level of household head with significant mean difference at 5\% level of significance (Table 4). This may probably mean that literate farmers have more exposure to the external environment and information which helps them easily associate to credit sources. An educated farmer is able to use modern agricultural technologies, perform farming activities based on cropping calendar, and manage resources properly. All these factors boost production, which improves loan repayment. It is known that education is the best instrument for the development of a country. The best way to solve various problems is educating the productive age group by using not only the formal education but also by non-formal educations.

Social Ceremonies: The analysis indicated that 108 (or 77.14 percent) respondents had celebrated one or more ceremonies during the year preceding the survey. Of the total respondents who had participated in a ceremony during the 2009/10 year, $29(26.85 \%)$ respondents were low performers while $79(73.15 \%)$ respondents were high performers. $28.13 \%$ of low performers and $71.87 \%$ of the high performer respondents were not celebrate any social ceremonies in the year 2009/10. Chi square tests indicated that there is no significant association between loan repayment performance and social festival.

Shock: Borrowers were also asked about the different shocks like family emergencies, crop/income loss due to natural calamities and others shocks occurred within the repayment period. The survey results revealed that $58.57 \%$ percent of the total respondents confirmed that there was a shock and the remaining $41.43 \%$ of the borrowers did not face shocks within the stated period. In addition, the results of the survey indicated that 65.79 and 55.88 percent of farmers in the low and high performance category respectively confirmed that there was shock that affects their repayment. The descriptive results of the survey also indicate 34.21 and 44.12 percent of farmers did not face shocks in the low and high performer category respectively.

Purpose of borrowing: Farm households usually borrow money for a wide range of purpose. About $55.26 \&$ $76.47 \%$ of low and high performer group used the borrowed money for the purchase of agricultural inputs with statistically significant mean difference between the purposes of borrowing by the two groups at $5 \%$ level of significance.

\subsection{Challenges for loan repayment}

Farm households also identify many problems that hinder their loan repayment performance. The summary of most frequently mentioned problems are the following:

Table 3: Distribution of challenges faced the borrowers in the repayment process

\begin{tabular}{|l|l|l|l|l|l|l|l|}
\hline \multirow{2}{*}{ Challenges faced by the borrower } & \multicolumn{4}{l|}{ Loan repayment performance } & \multicolumn{4}{l|}{ Chi2 } \\
\cline { 2 - 9 } & Low & & High & & Total & & \\
\cline { 2 - 9 } & No & $\%$ & No & $\%$ & No & $\%$ & $13.7 * * *$ \\
\hline High interest rate & 11 & 34.4 & 21 & 65.6 & 32 & 22.86 & $(0.008)$ \\
\hline Grace period is too short & 3 & 11.5 & 23 & 88.5 & 26 & 18.57 & \\
\hline Weak follow up and supervision & 4 & 21.1 & 15 & 78.9 & 19 & 13.57 & \\
\hline No guarantee against crop failure & 7 & 18.4 & 31 & 81.6 & 38 & 27.14 \\
\hline Lack appropriate training & 13 & 52.0 & 12 & 48.0 & 25 & 17.86 \\
\hline Total & 38 & 27.1 & 102 & 72.9 & 140 & 100 & \\
\hline
\end{tabular}

Note $* * *$ refers level significance at $1 \%$

Source: Own computation, 2018

* High interest rate. This implies that higher interest rate can cause shifting of clients into other institutions and also affect the borrower's repayment capacity because the borrowers are expected to pay both the principal and interest at a time.

* The grace period is too short. It is the period given by the financial institution to the borrower before the first installment is due. In other words, it is considered to be the time between when the loan was disbursed to the loan applicant and when the first installment is paid. ACSI grant only 3 month grace period before 
initial payment is expected.

* Weak follow up and supervision on the condition of loans due to inadequate infrastructure

* absence of protection or insurance against crop losses due to adverse climatic condition

* Lack of appropriate training: Providing training to the clients helps to aware the clients on many issues such as in the proposed business, on the area of entrepreneurship, on the issue of saving and on other related issues to support and strengthen the capacity of the borrower both on the repayment of their loan and in their life.

\subsection{Results of the Econometric Model}

Tobit model were used to determine the explanatory variables which are good predictors of the loan repayment performance of smallholder farmers. The Maximum Likelihood estimates of the Tobit regression model indicate that 13 variables were considered in the econometric model out of which, 7 variables were found to significantly influence loan recovery among the farm households. These were age of borrowers (AGEBOR), Educational status of borrowers (EDUSBOR), Distance to credit source (DCS), land size (LANDSZ), total livestock holding (TLU), Loan amount received (LOANREC), and Off-farm income (OFFINC). The results of the analysis are presented in the following table.

Table 4: Maximum likelihood estimates of the two-limit Tobit model

Number of obs $=140$
LR chi2 $(13)=157.88$
Prob $>$ chi2 $=0.0000$
Pseudo R2 $2=0.7927$
Log likelihood $=-20.649723$

\begin{tabular}{|l|l|l|l|l|l|l|}
\hline LRR & Coef. & Std. Err. & T & P>t & {$[95 \%$ Conf. } & Interval] \\
\hline AGEBOR & .0076903 & .0024065 & 3.20 & $0.002 * * *$ & .0029282 & .0124524 \\
\hline SEXBOR & .0519904 & .0451928 & 1.15 & 0.252 & -.0374379 & .1414188 \\
\hline FAMS & -.0219102 & .0163706 & -1.34 & 0.183 & -.0543046 & .0104843 \\
\hline EDUSBOR & .0964507 & .0259622 & 3.72 & $0.000 * * *$ & .0450762 & .1478251 \\
\hline CSC & -.0741273 & .0494957 & -1.50 & 0.137 & -.1720704 & .0238158 \\
\hline DCRS & -.021931 & .005969 & -3.67 & $0.000 * * *$ & -.0337427 & -.0101194 \\
\hline LANDSZ & .3860014 & .0615471 & 6.27 & $0.000 * * *$ & .2642108 & .5077921 \\
\hline LOANREC & -.0000101 & $3.70 \mathrm{e}-06$ & -2.74 & $0.007 * * *$ & -.0000175 & $-2.81 \mathrm{e}-06$ \\
\hline TLU & .0631722 & .0119802 & 5.27 & $0.000 * * *$ & .0394656 & .0868789 \\
\hline OFFINC & .0000117 & $5.28 \mathrm{e}-06$ & 2.22 & $0.029 * *$ & $1.25 \mathrm{e}-06$ & .0000222 \\
\hline MSBOR & .0626645 & .0504887 & 1.24 & 0.217 & -.0372435 & .1625725 \\
\hline SHOCK & -.036131 & .0434304 & -0.83 & 0.407 & -.122072 & .04981 \\
\hline PURBOR & .0503056 & .0485355 & 1.04 & 0.302 & -.0457374 & .1463486 \\
\hline cons & -.0511051 & .178361 & -0.29 & 0.775 & -.4040494 & .3018392 \\
\hline
\end{tabular}

Obs. summary: 0 left-censored observations

76 uncensored observations

64 right-censored observations at $\mathrm{LRR}>=1$

Note $* * *$ and $* *$ refers level significance at $1 \%$ and $5 \%$ respectively

Source: Own computation, 2018

Table 5: The marginal effects of change in explanatory variables

\begin{tabular}{|l|l|l|}
\hline \multirow{2}{*}{ Variables } & \multicolumn{2}{|l|}{ Effect of change in independent variable on dependent variable } \\
\cline { 2 - 3 } & Unconditional expected value & Conditional on being uncensored \\
\hline AGEBOR & .0057558 & .0040972 \\
\hline DCRS & -.0164144 & -.0116842 \\
\hline EDUSBOR & .0721889 & .0513861 \\
\hline LANDSZ & .2889043 & .2056504 \\
\hline LOANREC & $-7.58 \mathrm{e}-06$ & $-5.40 \mathrm{e}-06$ \\
\hline TLU & .0472815 & .0336563 \\
\hline OFFINC & $8.76 \mathrm{e}-06$ & $6.23 \mathrm{e}-06$ \\
\hline
\end{tabular}

The marginal effects of changes in explanatory variables from Tobit regression analysis were computed following the procedure proposed by McDonald and Moffitt (1980) and Maddala (1999). The derived values for the significant explanatory variables indicate the effects of change in independent variable on dependent variable. Age of the borrowers: It has positively related to the dependent variable and significant at $1 \%$. As age increased 
by 1 year, the rate of loan repayment increases by $0.58 \%$ for the whole borrowers. The implication is that older borrowers may accumulate more wealth than younger ones, they might be more aware on the financial management and they feel responsibility to pay their loans.

Distance from the credit source (DCRS): it is a continuous variable that measures distance in $\mathrm{km}$ of the residence of the sample households from the credit source. It has negative significant effect on loan repayment performance at $1 \%$ level of significance. Analysis of the marginal effect after Tobit revealed that if distance from the credit source increases by $1 \mathrm{~km}$, loan repayment rate decrease by 1.64 units among the total sample households. This implies that farmers near the lending institutions have advantageous on getting new information daily, save farm resources (time, labor) and loan officers could easily make continuous supervision as well as advisory visit on the way of borrowers' loan usage.

Education level of the borrowers (EDUBOR): Education level of the borrower positively affect the loan repayment rate at $1 \%$ significance level. Thus, as education level of the borrower improved by one grade level, the rate of loan repayment increased by $7.22 \%$ for the entire sample. This may be due to the fact that farmers with better education use the loan effectively and their ability to obtain, process, and use information increases as compared to those who have no any formal education. For example, educated farmers may seek information on prices more than the illiterates ones and consequently, will be able to sell their produce at reasonable prices. Moreover, education may enable farmers to develop the entrepreneurial skill and be more aware of the importance of formal loan.

Land size (LANDSZ): Land holding positively and significantly affects loan repayment rate of smallholder farmers at 1\% significance level. On average, one hectare increase in land holding of smallholder farmers increases the rate of loan repayment by $28.9 \%$ for the entire sample. As more and more land is brought under cultivation, farm- income is expected to increase due to the increased output. Therefore, having larger size of land enhances a borrower's capacity to repay his/her loan timely.

Loan amount received (LOANREC): It is among the economic factors that was negatively and significantly affected loan repayment performance of smallholder farmers at $1 \%$ significant level. Each additional unit of loan received decreases the rate of loan repayment by $7.58 \mathrm{e}-06$ for the entire respondents. This indicate as the amount of loan exceeds what the farmer needs and can handle, it will be more of a burden than help and extra funds may go toward personal use. Therefore, borrowers poorly perform loan repayment.

Livestock holding (Livestock): This is one of the explanatory variables that positively affect the loan repayment rate at $1 \%$ significant level. From the result obtained we can observe that an increase in amount of livestock holding by one Tropical Livestock Unit increases the loan repayment rate by $4.73 \%$ for the entire samples. This implies that livestock is one of the important household assets that can easily be changed to cash and serve as security when farmers face crop failure. Hence, they are forced to sale it to pay the loan.

Off-farm income (OFFINC): This variable positively and significantly affects loan repayment performance of smallholder farmers at less than $5 \%$ significance level. On average 1 birr increase in off-farm income results in an increase of loan repayment rate by $8.76 \mathrm{e}-06$ for the total sample households. This is due to the fact that offfarm activities are additional sources of income for smallholders and the cash generated from these activities could back up the farmers' income to settle their debt even during bad harvesting seasons and when repayment period coincides with low agricultural prices.

\section{Summary and conclusion}

It has been argued that one of the major problems for poor agricultural production and productivity is inability of the smallholder farmers to buy agricultural input. But in recent years the government and NGOs are trying their level best to access credits to farmers both in cash and agricultural inputs, especially fertilizers. Thus, the main objective of this study was to assess loan repayment performance of smallholder farmers in Gubalafto district of North Wollo Zone. A two-stage sampling technique was employed to select a total of 140 sample borrowers. The two-limit Tobit model and descriptive statistics were used to analyze the data collected from the sample respondents.

The descriptive statistics result indicates that about 27 percent of the sampled households are low performer and the remaining 73 percent were high performers of loan. In addition, the descriptive statistics results revealed that there were significant mean differences between the low and high repayment performance group in the study district with respect to age of the borrowers, sex, distance from credit source, education level, total land size. Loan amount received, livestock holding and purpose of borrowing.

The maximum likelihood estimate of the two Limit Tobit model results indicate that 13 variables were considered in the econometric model out of which, 7 variables were found to significantly influence loan repayment rate among the farm households at less than 5 percent level of significance. Age of borrowers, Educational status of borrowers, land size, total livestock holding and Off-farm income positively and significantly influenced the intensity of loan repayment while, Distance to credit source and Loan amount received negatively influenced the loan repayment rate of small holder farmers in the study area. Farm households also identify many 
problems that hinder their loan repayment performance. These are high interest rate, short grace period and weak follow up and supervision to recover loans. In line with this the institution has many internal and external challenges such as; high turnover of employees to other organization, the loan is given without proper evaluation of borrowers' loan application, poor documentation, weak monitoring and support system, competition and the government intervention to keep interest rates low.

Age of the borrowers is one of the significant determinants of loan repayment performance of smallholder farmers. Older borrowers may accumulate more wealth than younger ones, they might be more aware on the financial management and they feel responsibility to pay their loans. It is not recommended to exclude the young age groups but the institution should give special attention to those borrowers by continuous follow up and supervision. Education level of the household head positively and significantly affects the loan repayment performance. This clearly indicates that for effective utilization of improved technologies, enhancing the educational level of the farmers through adult education and the expansion of primary education should be given due attention.

The econometric results also indicated that as off farm income increase, loan repayment rate increase and farmers who were engaged in off farm activities earned more income and were able to pay its loan on time. This indicates that, rural development strategies should not only emphasize on increasing agricultural production but simultaneously give attention on alternative income generation activities that can help to improve the livelihoods of smallholders and also help to increase loan repayment rate.

Land size positively affects loan repayment performance of smallholder farmers. As farming land is getting smaller and smaller with increasing farming families, diversification of farm activities for additional income is imperative. So the lending institutions should give attention to other income generating activities on farm. The expansions of other source of income with diversified business plan will hedge smallholders' against natural calamities. Livestock holding positively affect the loan repayment performance and serve as an important source of livelihood and cash in rural areas which increase farmers' loan recovery by generating additional income. Therefore, attention should be given for scientific livestock management system, which is relevant for the welfare of rural households. Hence, effort should be made to improve livestock genetics, provide appropriate nutrition and health service.

Finally, the institution should focus on the repayment challenges which are stated by the borrowers and take corrective actions. Institutions also improve their financial capacity and expand their services to solve the internal and external problems.

\section{ACKNOWLEDGEMENT}

Special thanks to my brother Melaku Belay, Wollo University, Ethiopia.

\section{REFFERENCES}

Abebe Mijena, 2011. Determinants of Credit Repayment and Fertilizer Use by Cooperative members in Ada District, East Shoa Zone, Oromiya Region: M.A Thesis. Department of Agricultural Economics, Haramaya University, Ethiopia

Abraham Gebeyehu, 2002. Loan repayment and its determinants in small scale enterprises financing in Ethiopia, M.Sc. Thesis, Addis Ababa University, Ethiopia

Amare Birhanu, 2005. Determinants of formal source of credit loan repayment performance of small holder farmers. M.Sc. Thesis. Haramaya University, Ethiopia

Asnake Wereta, 2014. Factors that Affect Loan Repayment Performance of Smallholder Farmer Borrowers From Microfinance Institutions in Ethiopia: A Survey Study of Amhara Credit And Saving Institution (ACSI)Fogera Woreda, Amhara International Journal of Research in Commerce, Economics \& Management,Vol.4(6)

Aja Okorie, 2004. Major Determinant of Agricultural Smallholder Loan Repayment in Developing Economy: empirical evidence from Ondo state Nigeria, University of Nigeria 211:4, 223-234

Anbes Tenaye, 2007. Impacts and Implications of Agricultural Credit Use on Gross Farm Income in Southern Ethiopia: M.Sc. Thesis, Norwegian University of Life Sciences, Norway

Bekele Hundie, 2001. Factors Influencing the Loan Repayment Performance of Smallholders in Ethiopia: M.Sc. Thesis, Alemaya University, Ethiopia

Belay Abebe, 2002. Factors Influencing Loan Repayment of Rural Women in Eastern Ethiopia: The Case of Dire Dawa Area, M.Sc. Thesis, Alemaya University, Ethiopia.

Cochran, W. G. (1963). Sampling Techniques, 2nd Ed., New York: John Wiley and Sons, Inc.

Central Stastical Authority (2007). Federal Democratic Republic of Ethiopia, Office of Population and housing census commission: Addis Ababa, Ethiopia.

Dadson A (2012). Determinants of loan repayment default among farmers in Ghana, Journal of Development and Agricultural Economics Vol. 4(13), pp. 339-345.

Daniel Belay, 2006. Performance of primary agricultural cooperatives and determinants of members' decision to 
use as marketing agent in Ada'a Liben and Lume districts: M.Sc. Thesis Presented to Haramaya University, Ethiopia.

Fikirte Reta, 2011. "Determinants of loan repayment performance: A case study in the Addis Credit and Saving Institution." Addis Ababa, Ethiopia

Firafis Haile, 2014. Determinants of Loan Repayment Performance of Smallholder Farmers: Case study of Harari microfinance, journal of agricultural development and rural development, vol.7 (2), pp 56-64.

Gebrehiwot Teklu, 2007. Credit utilization and loan repayment performance of agricultural service cooperatives in Enderta District, Tigray: M.Sc. Thesis Presented to the Haramaya University, Ethiopia.

Gerald A, Deogratius A, 2013. Credit rationing and loan repayment performance: The case study of Victoria savings and credit cooperative society. Vol. 2(6) pp. 328-341

Howard B. Lee Gary S. Katz Alberto F. Restori (2010): The Application of Canonical Correlation to TwoDimensional Contingency Tables. California State University, Northridge, Vol. 6(1), p. 1-15.

Jemal Abafita, 2002. Microfinance and Loan Repayment Performance: A Case Study of the Oromiya Credit and Savings Share Company (Ocssco): Msc. Thesis, Addis Ababa University, Ethiopia.

Kibrom Tadesse, 2010. Determinants of successful loan repayment performance of private borrowers in Development Bank of Ethiopia North Region: Msc thesis. Mekelle University, Ethiopia.

Mohad, N. (2010). Determinants of Repayment Performance in Microcredit Programs: A Review of Literature, International Journal of Business and Social Science Vol.1 (2).

Maddala, G.S. (1992). Introduction to Econometrics: Second Edition. Macmillan Publishing Company, New York

Nawai N, Sharif M (2012). Factors affecting repayment performance in microfinance programs in Malaysia: presidia. Social and Behavioral sciences, 62,806-811

Osman Y. (2017). Determinants of loan repayment performance in ACSI: International Journal of Advanced Research in Management and Social Sciences, Impact Factor: 6.943, ISSN: 2278-6236, Vol. 6 | No. 4 |

Oladeebo, O.E., 2008. Socio-Economic Factors Influencing Loan Repayment among Small Scale Farmers: In Ogbomosho Agricultural Zone of Oyo State, Nigeria.

Robert F. M (2014). Factors affecting loan repayment behavior in Tanzania: Empirical evidence from Dar es Salaam and Morogoro regions, International Journal of Development and Sustainability. Volume 3 Number 3 (2014): Pages 481-492 ISDS Article ID: IJDS13032103

Samson J. (2003). Financial Arrangements and Determinants of Consumption Credit use by Rural Households: The Case of Loume Woreda, M.Sc, thesis, Alemaya University, Ethiopia.

Samuel Setargie, 2011. Credit Default Risk and its Determinants of Microfinance Industry in Ethiopia, Aksum University, College of Business and Economics

Sheik A. Tolosa N, 2014. Eurasian Journal of Business and Economics: Performance of Loan Repayment determinants in Ethiopian Micro Finance - An Analysis 7 (13)

Seleshi M., Nyikal R. and Wangia S. (2012): "Factors Affecting Loan Repayment Performance of Smallholder Farmers in East Hararghe, Ethiopia.” Developing Country Studies, Vol 2, No.11.

Selam Abera, 2016. Determinants loan repayment performance: the case of micro and small enterprises in Dire Dawa administration. Haramaya University, Ethiopia.

Schreiner, M. (1997): “Two Measures of the Costs of Subsidized Development Finance Institutions”, Intl. Rural Finance Seminar Series, The Ohio State Univ., Oct. 30.

Sisay Yehula, 2008. Determinants of Smallholder Farmers Access to Formal Credit: The Case of Metema Woreda, North Gondar, Ethiopia. M.Sc. Thesis. Haramaya University, Ethiopia.

Solomon Etaye, 2013. Factors influencing formal loan repayment performance of urban women in Tigray, A case study of Dedebit credit and saving institution, Adwa town woreda, Mekelle University.

Tobin, J., (1958). Estimation of Relationships for Limited Dependent Variables: Econometrica. 26:24-36.

UNDP (United Nations development program) report, 2005

Godwin C. O, Ibeleme .S, Odionye.J, Chukwudi (2013): Loan repayment performance of small holder oil producers in Nigeria: a credit rating approach Journal of Research in Economics and International Finance (JREIF) (ISSN: 2315-5671) Vol. 2(5) pp. 88-96

Warren F. Lee. Hopkin, (1983): Credit management. Dept. of Agricultural Economics and Rural Sociology Ohio State University

Wonga C. A. and Awunyo-Vitor D. (2013) "Factors affecting loan repayment performance. Among Yam farmers: Sene district, Ghana.” Agris on-line Papers in Economics Informatics Vol. No. 2

Zelalem Gebeyehu, 2013. Determinants of Loan Repayment Performance of Smallholder Farmers: The Case of Kalu District, South Wollo Zone, Amhara National Regional State, Ethiopia, International Journal of Economics, Business and Finance Vol. 1( 11), PP: 431- 446 